\title{
The Effect of Cannabis Sativa Leaves Aqueous Extract on Cerebral Cortex in Albino Rats
}

\author{
D. S. Amaza ${ }^{1 *}$, F. A. Maidugu ${ }^{1}$, J. V. Zirahei ${ }^{1}$, A. I. Numan ${ }^{1} \&$ Hyelnada Mari ${ }^{2}$ \\ ${ }^{l}$ Department of Human Anatomy, College of Medical Sciences, University of Maiduguri, Borno State, Nigeria \\ ${ }^{2}$ Department of Biological Sciences, Faculty of Sciences, University of Maiduguri, Borno State, Nigeria
}

\begin{abstract}
Aims: To Determine The Effects Of Aqueous Leaf Extract Of Cannabis Sativa On The Cerebral Cortex Of Wister Rats.

Study design: Experimental study.

Place and Duration of Study: Department of Human Anatomy, University of Maiduguri Borno State, Nigeria, between June 2010 and July 2011

Methodology: Dried leaves of $297 \mathrm{~g}$ of cannabis sativa were blended into fine powdered form. The powdered form was soaked in 2 litres of distilled water and was evaporated to yield extract of total weight of 27.2g, which was stored at room temperature until ready for use. Twenty (20) adult Wister rats of both sexes weighing between $110.0 \mathrm{~g}$ to $230.7 \mathrm{~g}$ were used. The rats were kept in a cross-ventilated room $(12 \mathrm{hr}$ light/12 hr dark cycles) of animal house of the Department of Human Anatomy, University of Maiduguri for acclimatization. The rats were individually labeled and were feed with standard vital feeds (livestock feeds, Maiduguri) and water ad libitum. The rats were randomized into 4 groups of 5 each. Groups B-D served as experimental, each group received 500, 750, and $900 \mathrm{mg} / \mathrm{kg}$ respectively of the extract while Group A (control) received distilled water in equivalent dosage level. The rats were all fed oro-gastrically by intubation once daily for 28 days. All the animals were sacrificed on day $29^{\text {th }}$ day by cervical dislocation, and the brain were rapidly dissected and then processed for light microscopic study.

Results: The cerebral cortex of rats treated with $500 \mathrm{mg} / \mathrm{kg}$ of cannabis extract showed lymphocytic cuffing, neutrophilic spacing and congestion of the vascular channel. At $750 \mathrm{mg} / \mathrm{kg}$ treatment, cerebral cortex showed multi-focal congestion of vascular channel However, perivascular congestion and lymphocytic infiltration characterized the cortex of rats treated with $900 \mathrm{mg} / \mathrm{kg}$. When compared with the control, the experimental animals had gradual increase in the mean values over a period of time in PCV, $H B, W B C$ and $M$; but in N, there was a decrease in group $B$ with an increase in the rest groups. In groups $B$ and $E$, the mean value almost remained steady throughout the period of the experiment. There was significant differences in the mean values only in $W B C(P<0.01)$.

Conclusion: Oral administration of cannabis sativa at varied concentration has the potential to cause damage to cerebral cortex as seen in Albino Rats. Further studies on the recovery group and particular cell-type damaged are hereby recommended.
\end{abstract}

Keywords: [Cannabis sativa; cerebral cortex; wister rats; aqueous extract]

\section{Introduction}

Medicinal plants have been used as healing agents in many parts of the world especially Africa where access to formal health care is limited [1]. Cannabis sativa also known as pot, grass, weed, hemp, blow, puff and marijuana among many other names refers to any number of preparation of cannabis sativa intended for use as a psychoactive drug [2]. According to Morrison et al (2007), the main active ingredient in marijuana is THC known as the delta 9 tetrahydrocannabinol which increases and not decreases anxiety [1,3,4]. Cannabis is not, as widely perceived a harmless drug but poses risks to the individual and to society, Humans have long used of the plant as medicine and spiritual tool [5]. Preparation of flowers marijuana and leaves are consumed by smoking, vaporizing and oral ingestion [6]. The medicinal use of this plant includes the treatment of glaucoma, depression and to relieve the nausea associated with the cancer treatment [7]. Its whole seed are also good source of phosphorous, magnesium, zinc, copper, and manganese; in facts hemp foods has no known allergies [8]. Life time cannabis use has been reported to be as high as $64.4 \%$ in patient with schizophrenia $[9,10,11,12]$. Brady et al. (2009) Reported that Cannabinoid receptors are divided into CB1 and CB2: CB1 receptors which are mainly found in the brain, but they can also be found in the kidneys, lungs and liver. CB2 receptors are found in the immune system and hematopoietic cells. CB1 and CB2 are G-protein receptors and when activated by cannabinoids, affect many intracellular structures such as calcium channels and protein kinase A. Cannabinoids acts as immunodulators at CB2 receptors [13]. It is possible that cannabinoid receptors in our body interact with the cannabinoids in milk to stimulate a suckling response in newborns so as to prevent growth failure. The literatures on histological study of tissues using plant cannabis sativa have been inadequate especially in 
Nigeria. Therefore, this work is to demonstrate the effects of aqueous extract of cannabis sativa on the histology of the cerebral cortex of Wister rat.

\section{Material And Methods}

\subsection{PLANT MATERIAL}

Cannabis sativa (CS) dried leaves was obtained from the Nigeria Drug Law Enforcement Agency, Maiduguri Borno State. The plant was identified by Prof. S.S Sanusi, a botanist in the Department of Biological Sciences, university of Maiduguri. It was then deposited in the Department of Human anatomy, University of Maiduguri, Nigeria.

\subsubsection{PREPARATION OF PLANT EXTRACT}

The dried leaves of $297 \mathrm{~g}$ of cannabis sativa were blended into fine powdered form. Then the powdered form was soaked in 2 litre of distilled water and was evaporated to yield extract of total weight of $27.2 \mathrm{~g}$, which was stored at room temperature until ready for use.

\subsection{METHODS}

\subsubsection{ANIMALS AND TREATMENT}

Twenty (20) adult Wister rats of both sexes weighing between $110.0 \mathrm{~g}$ to $230.7 \mathrm{~g}$ were used. The rats were kept in a cross-ventilated room (temperature $28 \pm 2.0 \mathrm{oC} 12 \mathrm{hr}$ light $/ 12 \mathrm{hr}$ dark cycle) of animal house of the Department of Human Anatomy, University of Maiduguri for acclimatization. The rats were individually labeled and were feed with standard vital feeds (livestock feeds, Maiduguri) and water ad libitum. The rats were randomized in 4 groups of 5 each. Groups B-D (experimental), each received 500, 750, and 900mg/kg respectively and Group A (control) received distilled water in equivalent dosage level. They were all fed orogastrically by intubation once a day for 28 days. All the animals were sacrificed on day 29 by cervical dislocation and the brain were rapidly dissected and then processed for light microscopy study.

\subsection{GROSS ANATOMICAL OBSERVATION}

\section{Results And Discussion}

During the experiment animals showed some physical changes such as hyperactivity, increase in appetite, and increase in weight (Table 1). Animals in control did not show any of these physical changes. This study document that mean body weights over time increases in group A than B, C and D in both control and experimental animals; but there was an increase in the weight of group $\mathrm{C}$ than $\mathrm{B}$ and $\mathrm{D}$ while $\mathrm{D}$ increases in weight than B. However, the CS-treated animals recorded an increase in body weight when compared with control in the entire groups studied. There was no significant difference $(\mathrm{P}>0.05)$ (Table 1).

Table 1: Effect of Cannabis sativa extract on the Mean Body Weight of Rat

\begin{tabular}{|c|c|c|c|}
\hline \multicolumn{4}{|c|}{$\mathrm{N}=5$ per group } \\
\hline Group/dose & $\begin{array}{l}\text { Control } \\
(g \pm \text { SEM })\end{array}$ & $\begin{array}{l}\text { CS- treated } \\
(\mathrm{g} \pm \mathrm{SEM})\end{array}$ & $\begin{array}{l}\text { Difference between Control } \\
\text { and CS- treated }(\mathrm{g} \pm \mathrm{SEM})\end{array}$ \\
\hline A (control) & $226.52 \pm 4.55$ & $249.12 \pm 9.74$ & $22.6 \pm 5.19$ \\
\hline B (500mg/kg) & $143.56 \pm 12.34$ & $157.44 \pm 12.12$ & $13.88 \pm 0.21$ \\
\hline C (750mg/kg) & $154.44 \pm 7.31$ & $172.24 \pm 9.91$ & $17.8 \pm 2.60$ \\
\hline D $(900 \mathrm{mg} / \mathrm{kg})$ & $152.56 \pm 6.49$ & $159.34 \pm 6.65$ & $14.86 \pm 0.16$ \\
\hline \multicolumn{4}{|c|}{$\mathrm{P}$ value $>0.05$} \\
\hline
\end{tabular}

\subsection{HISTOLOGICAL OBSERVATION.}

The cerebral cortex is made up of neurons and neuroglia as well as other connective tissues. Like the rest nervous system, the neurons are the functional units of the nervous tissue and damage to nervous tissue can occur in various ways [14]. Chronic, acute and acute-on-chronic administration of drugs has the potential to cause cerebral cortex damage.

The cerebral cortex of rats treated with $500 \mathrm{mg} / \mathrm{kg}$ of cannabis extract showed lymphocytic cuffing, neutrophilic spacing and congestion of the vascular channel (Fig 2). At $750 \mathrm{mg} / \mathrm{kg}$ treatment, cerebral cortex showed multi focal congestion of vascular channel (Figs3 \& 4). However, perivascular congestion and lymphocytic infiltration characterized the cortex-treated at $900 \mathrm{mg} / \mathrm{kg}$ (Figs $5 \& 6$ ), compared to control group (Fig 1). 


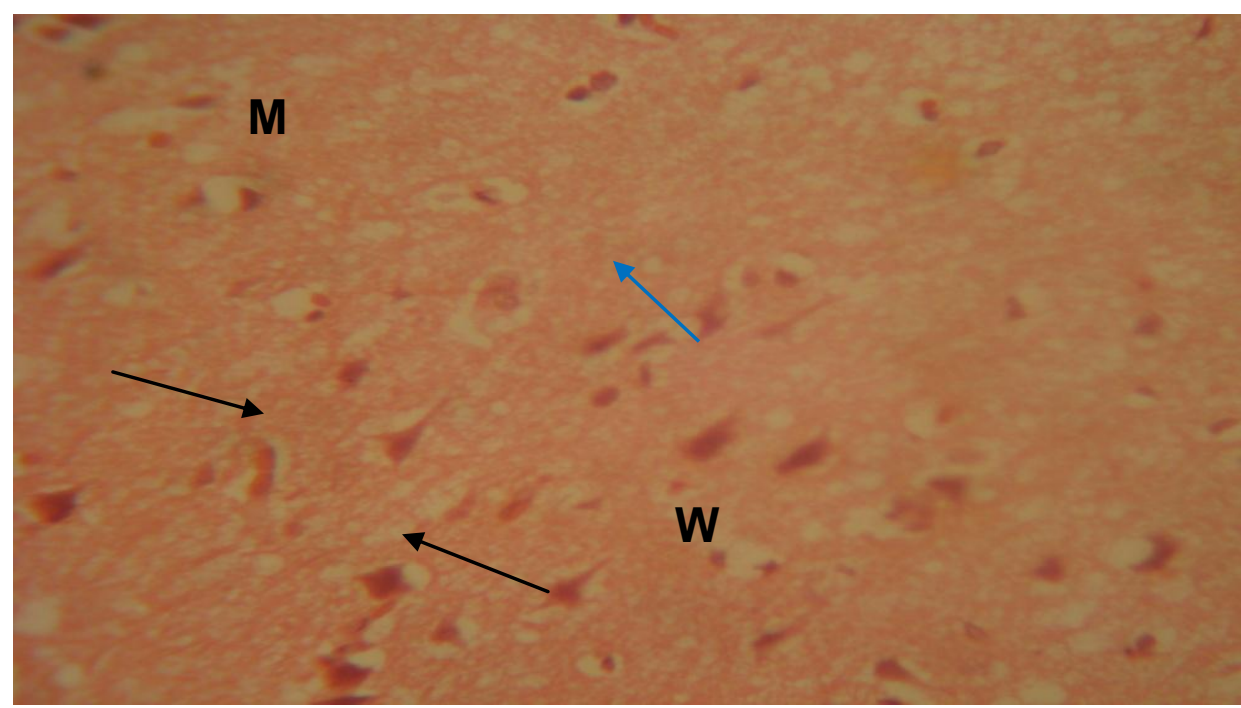

Fig 1: Photomicrograph of cerebral cortex of Control rat showing normal molecular layer (M), granular player (W) with pyramidal cells (arrows) and neuroglial cell nucleus (Blue arrows) H\&E x400.

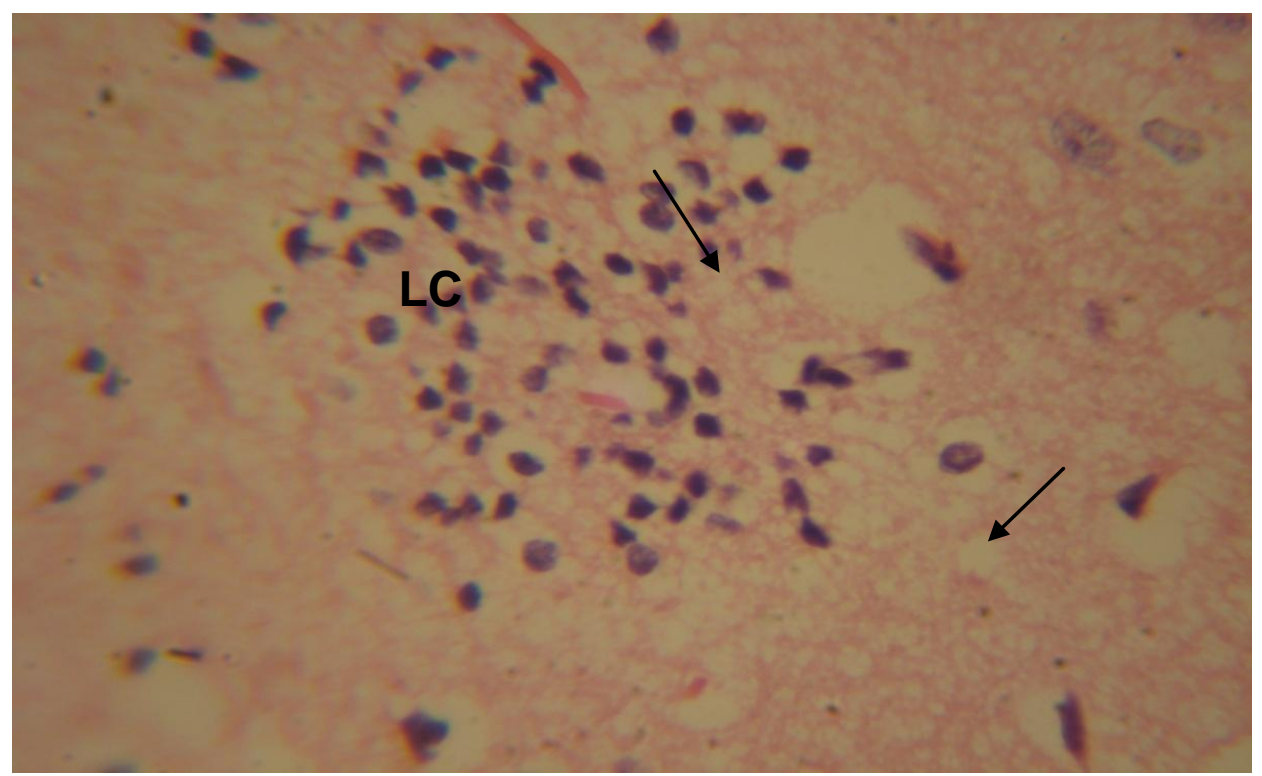

Fig 2: Photomicrograph of cerebral cortex of rat brain showing lymphocytic cuffing (LC) and neurophil space (arrows) H\&E x100 (B) $500 \mathrm{mg} / \mathrm{kg}$

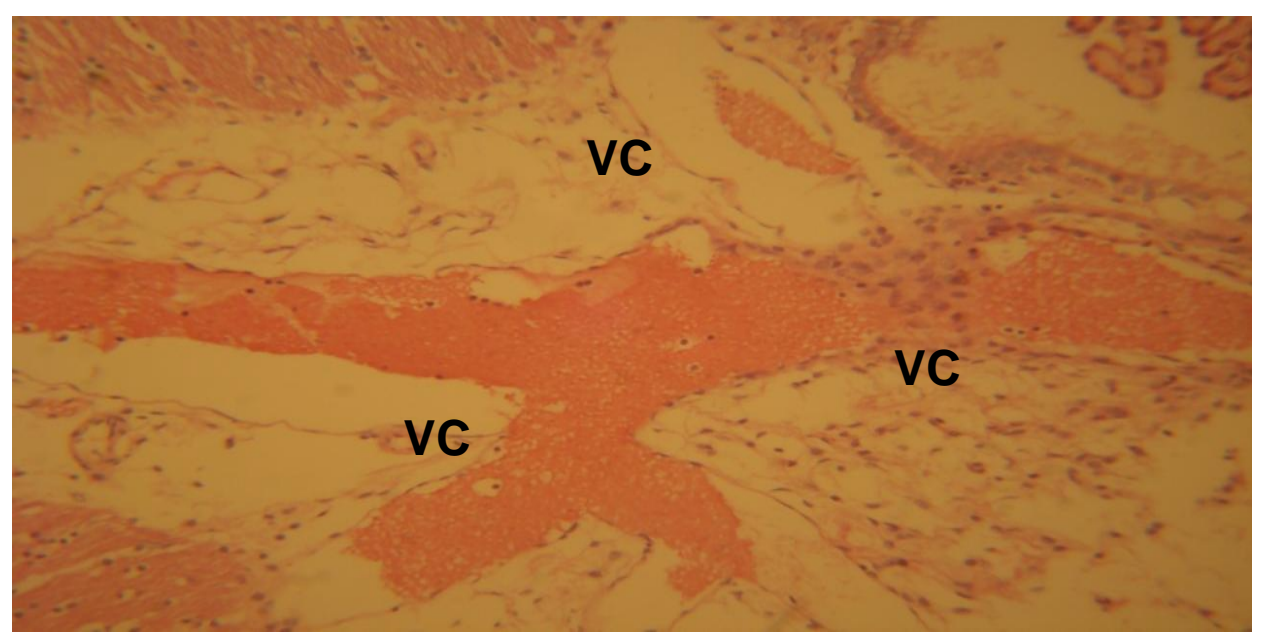

Fig 3: Photomicrograph of cerebral cortex of rat brain showing multi-focal congestion of vascular channel (VC) H\&E x400 (C) $750 \mathrm{mg} / \mathrm{kg}$ 


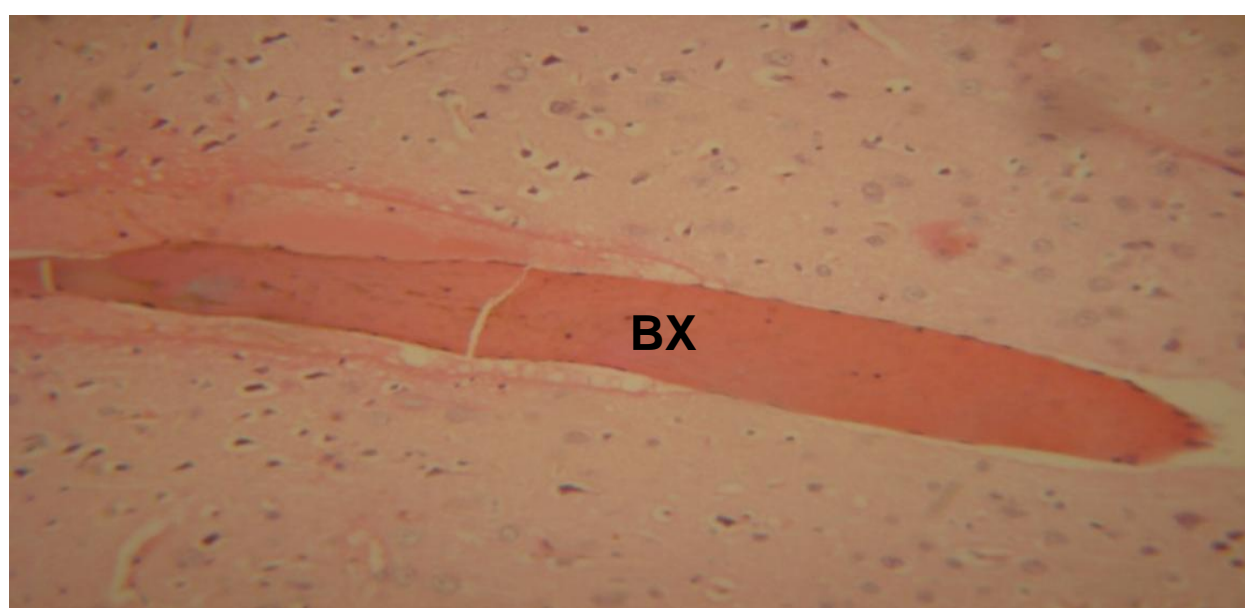

Fig 4: Photomicrograph of cerebral cortex of rat brain showing congestion of vascular channel (BX) H\&E x400 (C) $750 \mathrm{mg} / \mathrm{kg}$

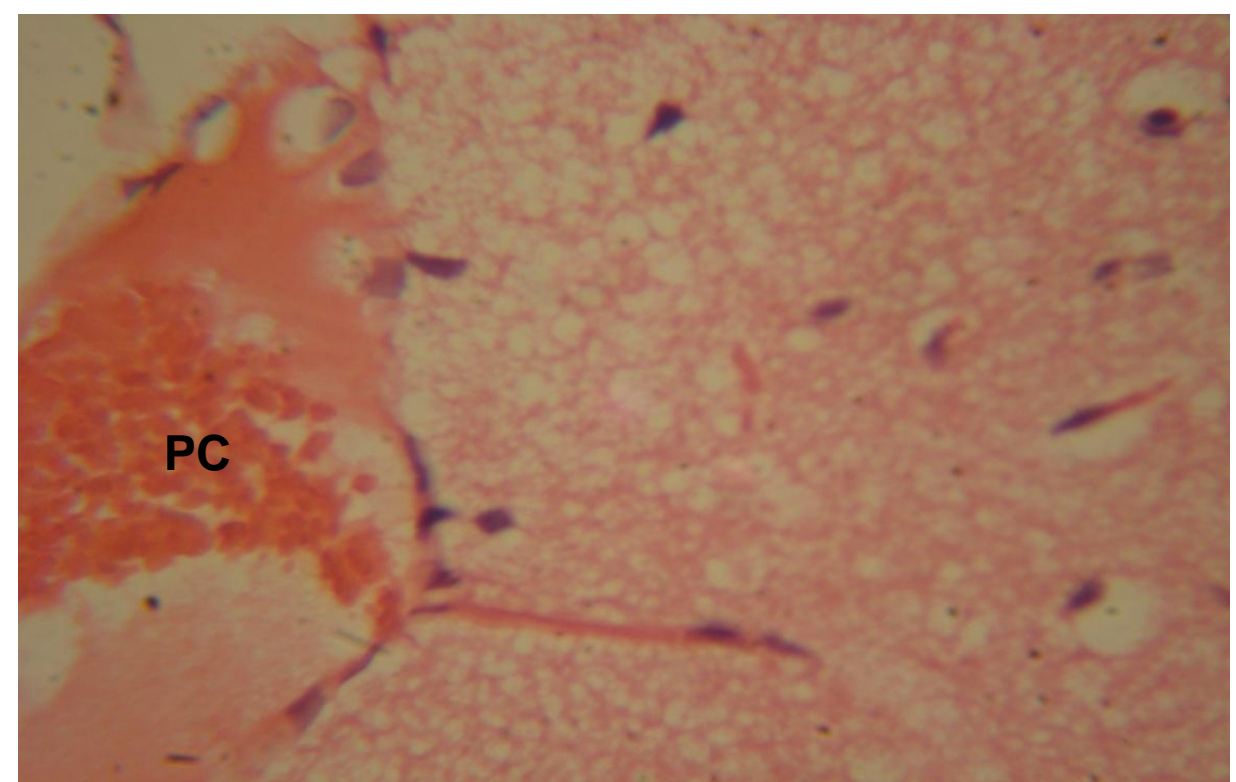

Fig 5: Photomicrograph of cerebral cortex of rat brain showing perivascular congestion (PC) H\&E x400 (D) $900 \mathrm{mg} / \mathrm{kg}$

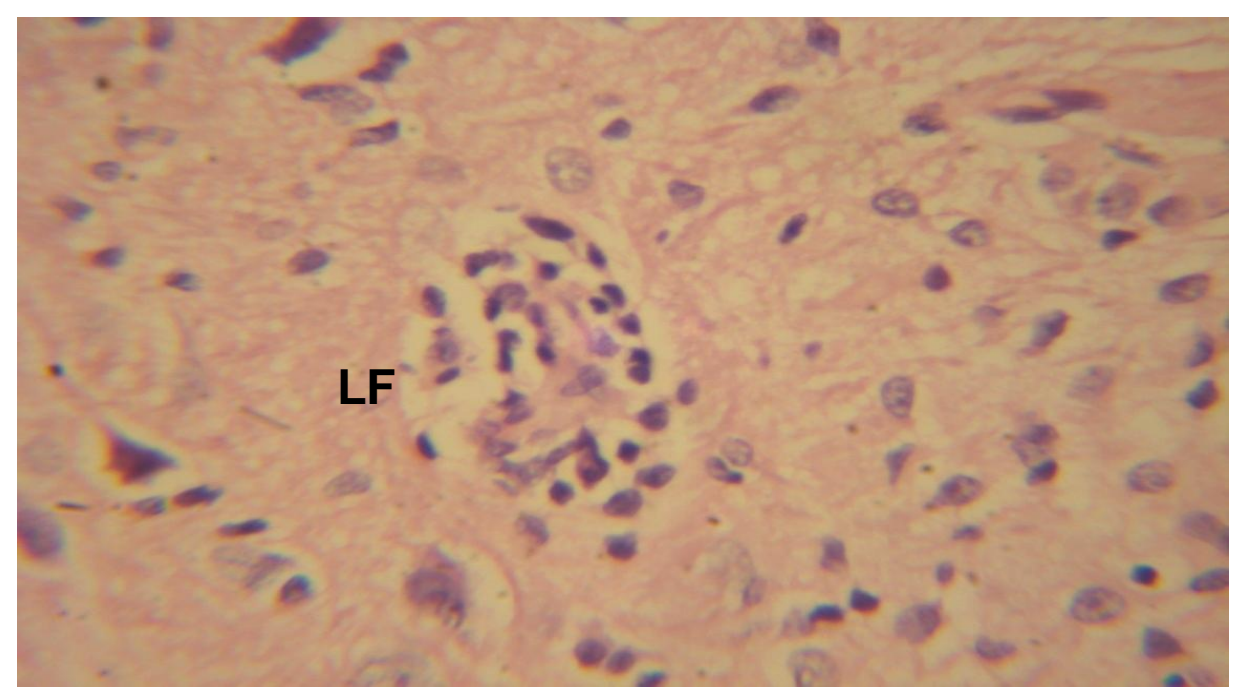

Fig 6: Photomicrograph of cerebral cortex of rat brain showing lymphocytic infiltration (LF) H\&E x400 (D) $900 \mathrm{mg} / \mathrm{kg}$ 
Table 1.Changes in the Haematological Parameters of the Control and Experimental Rats

\begin{tabular}{|c|c|c|c|c|c|c|c|c|}
\hline Grp/dose & $P C V$ & $H B$ & $W B C$ & $N T$ & $L$ & $M$ & $B$ & $E$ \\
\hline $\mathbf{A}$ & 0.336 & 11.88 & 9.22 & 63.4 & 35.8 & 1.4 & 1.4 & 1.4 \\
\hline (control) & \pm 0.05 & \pm 1.62 & \pm 1.33 & \pm 2.71 & \pm 2.38 & \pm 0.25 & \pm 0.25 & \pm 0.25 \\
\hline & 0.452 & 15.14 & $14.0 \pm$ & 61.6 & 36.6 & 3.0 & 1.4 & $1.6 \pm$ \\
\hline$(500 \mathrm{mg} / \mathrm{kg})$ & \pm 0.01 & \pm 0.48 & 0.71 & \pm 3.70 & \pm 4.39 & \pm 0.71 & \pm 0.25 & 0.25 \\
\hline & 0.464 & 15.28 & 13.06 & 66.6 & 33.2 & 1.6 & 1.2 & 1.4 \\
\hline$(750 \mathrm{mg} / \mathrm{kg})$ & \pm 0.02 & \pm 0.56 & \pm 1.42 & \pm 3.40 & \pm 3.26 & \pm 0.25 & \pm 0.20 & \pm 0.55 \\
\hline & 0.402 & 13.54 & 11.26 & 65.6 & 33.2 & 1.6 & 1.6 & 1.4 \\
\hline$(900 \mathrm{mg} / \mathrm{kg})$ & \pm 0.02 & \pm 0.70 & \pm 0.73 & \pm 2.32 & \pm 2.4 & \pm 0.25 & \pm 0.25 & \pm 0.25 \\
\hline$P$ value & ${ }^{\mathrm{N}} 0.5102$ & ${ }^{\mathrm{N}} 0.0904$ & ${ }^{\mathrm{s}} 0.0129$ & ${ }^{\mathrm{N}} 0.7035$ & ${ }^{\mathrm{N}} 0.8766$ & ${ }^{\mathrm{N}} 0.0650$ & ${ }^{\mathrm{N}} 0.999$ & ${ }^{\mathrm{N}} 0.5796$ \\
\hline
\end{tabular}

Grp = group, $\mathrm{mg}=$ gram, $\mathrm{P}=$ probability, $\mathrm{N}=$ not significant, $\mathrm{S}=$ significant, $\mathrm{PCV}=$ packed cell volume, $\mathrm{WBC}=$ white

blood cell, $\mathrm{NT}=$ neutrophil, $\mathrm{L}=$ lymphocyte, $\mathrm{M}=$ monocytes, $\mathrm{B}=$ basophil, $\mathrm{E}=$ eosinophil.

When compared with the control, the experimental animals had gradual increase in the mean values over a period of time in $\mathrm{PCV}, \mathrm{HB}, \mathrm{WBC}$ and $\mathrm{M}$; but in $\mathrm{N}$, there was a decrease in group $\mathrm{B}$ with an increase in the rest groups. In groups $\mathrm{B}$ and $\mathrm{E}$, the mean value almost remained steady throughout the period of the experiment. There was significant differences in the mean values observed only in WBC $(\mathrm{P}<0.01)($ Table 2$)$.

The histological observation of the sectioned cerebral cortex showed that rats administered with $500 \mathrm{mg} / \mathrm{kg}$ of the extract revealed lymphocytic cuffing and that of medium dose group of $750 \mathrm{mg} / \mathrm{kg}$ of extract showed multifocal congestion of vascular channel as to compare to the control group.

The administration of $900 \mathrm{mg} / \mathrm{kg}$ of the extract showed perivascular congestion as well as lymphatic infiltration. This study was in agreement with study conducted by [15] who reported that there were changes in the neurons in selected brain regions as to the administration the same drug. It was also observed by Andreas et al, (2005) who reported that there were morphological changes in the basal lamina of the brain of poly users.

The lymphocytic cuffing is the accumulation of lymphocytes or plasma cells in a dense mass around a vessel which shows an indication of inflammation or of an immune reaction of the cerebral cortex. The multifocal congestion of vascular channel is also known as a progressive multifocal leukocephalitis is a rare and usually fatal viral disease that is characterized by progressive damage or inflammation of the white matter of the brain at a multiple location of the white matter of the brain (multifocal). It occurs almost exclusively in people with severe immune deficiency [17]. In another study by Amna and Nabiela 2011 showed that total white cells count decreased significantly in all treated rats and was due to the significant reduction of the neutrophils and lymphocytes percentages. Therefore it has been demonstrated that administration of the aqueous cannabis extract could cause varying degree of neurodegenerative changes in the cerebral cortex of albino rats.

\section{Conclusion}

These findings have therefore revealed that administration of the aqueous extract of cannabis sativa caused varying degree of neurodegenerative changes in the cerebral cortex of albino rats. Therefore consumption of cannabis sativa should be discouraged due to damage that may occur to the cells in the cerebral cortex. Further studies on the recovery group and particular cell-type damaged are hereby recommended.

\section{Acknowledgements}

The authors are grateful to all the staff of Nigeria Drug Law Enforcement Agency (NAFDAC) Maiduguri Branch Borno for Cannabis Sativa given to us, and also to the Ethical committee for their kind approval that lead to the success of this study. 


\section{COMPETING INTERESTS}

Authors have declared that no competing interests exist.

\section{References}

[1]. Morrison, P.D, Zois, V.mckeown, D.A. Lee T. D. Hoel D.W. Powell, J.F Kapur, S and Murray, R.M (2009). The acute effects of synthetic intravenous delta- 9- tetrahydrocannabinol on psychosis and mood and cognitive functioning psycho Med. 39: 1607-1616.

[2]. John H. Wiersena. Cannabis sativa Information from NPGS/ GRIN Avs-grin. Gov. Retrieved 2010

[3]. Fusarpoli;P. Crippa, J.A Bhattacharry, S. Borgwardt, S.J Allen, P Martin- Santos, R. Seal, M. Surguladze, S.A O. Carol, C. Atakan, Z. Zuarch, A.W and Mc Guire, P.K (2009) Distinct effects of delta 9- tetrahydrocannabinol and Cannabidiol on neuro activitation during emotional processing Arch gen psychiatry 66: 95-105.

[4]. Essential Oils of different cultivars of Cannabis Sativa L. and their antimicrobial activity. Flavour and Fragrance Journal 16,14: (259-262). Florida 1996-2010

[5]. Brady, J., R. Curtis and J. Nothstein, 2009. Medical Attributes of Cannabis sativa-Marijuana. Wilkes University. Wilkes-Barre, PA.

[6]. West. D.P Ph.D (2007). Hemp and Marijuana Myths and Realities, North American Industrial Hemp council.

[7]. Foster, Steven and Duke, James A. (1990) Boston Hough Mifflin ISBN 395-467. 225

[8]. Van Roekel, Gerijan J (1994) Hemp pulp and paper Production Journal of International Hemp Association (Wageningen).

[9]. Loberg, E.M, Jorgensen, H.A, and Hugdalie (2003). The effects of previous Drug Abuse on Neurocognition in Schizophrenia Abstract J. Int. Neuropsychol. Soc 9: 172

[10]. D’Sounza, D,c, Abi Saab, W. M Madonick, S, Forselus Bielen K. Doersch A. Braley G. Gueorguieva R.Cooper T.B and Kryatal J.H (2005) Delta 9- tetrahydrocannabinol effects in schizophrenia implications of cognitions psychosis and addiction Biol. Pscychiatry 57: 594-608

[11]. Barnes, T. R Mutsatsa, S.H Hutton, S.B. Watt, H.C and Joyce E.M (2006). Comorbid substance use and agent of Schizophrena.

[12]. Ranganathan, Mohini, D'souza, Deepak Cyril (2006), The acute effects of cannabinoids on memory in human Review psychopharmacology 188 (4) 425-44

[13]. Pertwee, R (1997). Pharmacology of Cannabis CB1 and CB2 receptors: pharmacology and therapeutic 74:129-80.

[14]. Inderbir Singh, (2006), 7th edition Textbook of Human Neuroanatomy, 263-74.

[15]. Una D. Mccann, Kelly A. Lowe and George A. R. Caurte. (1997) Neuroscience Biological psychiatry branch Bethseda Maryland Department of Neurology John Hopkins Medical Institution Baltimoore Maryland.

[16]. Andreas Butter, Claus Kroehling, Crita Mall, Randolphin Penning and Serge well.(2005)Institute of Legal Medicine Ludwig Maximillians University, Frauenlobstrasse 7a, 80337 Munich, Germany.

[17]. Jaime M. Kean, Suchitra Rao, Micheal Wang and Robert L. Garcea (2009) Seroedidermorlogy of Human Polymovirus Phosepathog $5(3)$.

[18]. Amna H. Mukhtar and Nabiela M. Elbagir (2011). Effects of Cannabis Sativa on Hematological Indices in Rats and Men. Pakistan Journal of Nuti. 10(4):313-316 